\title{
THE ADAMS-STOKES SYMPTOM-COMPLEX, WITH REPORT OF A CASE.'
}

\author{
By ClaARence Quinan, M.D., \\ INFTRUCTOR IN MEDICINE, MEDICAL DEPARTMENT, UNIVERSITY OF CALIFORNIA; REAEARCH \\ SCHOLAR OF THE ROCKEFELLR INSTITUTE FOR MEDICAL RESEARCH.
}

In 1893 Huchard proposed the name Adams-Stokes disease for a remarkable symptom-complex characterized by temporary or permanent bradycardia, loss of consciousness, together with apoplectic or epileptiform seizures. According to him the condition is usually if not exclusively encountered in individuals of advanced years, and is indicative of arteriosclerosis of the cardiobulbar type.

The first authentic case was reported by Adams in 1827, but those of Stokes, published in the early fifties, were better described and have been more-frequently cited. A long interval elapsed before the observations of these earlier writers were accorded proper recognition, though other clinicians reported cases from time to time that were similar in every essential point. Among the more important contributions of this period are the papers of Cornil (1875) and Handfield Jones (1876). Both of these authors accurately outlined the peculiar symptom group and described cases that undoubtedly must be included in the same category with those of Adams and Stokes.

It was not until after Huchard had suggested a definite pathological basis for the complex that it was submitted to critical analysis, and some years passed before it was accepted as a distinct clinical entity. Case reports of more or less interest appeared in considerable numbers at this time, and we find casual mention of the condition in the text-books of Balfour (1894) and Edgren (1898). In 1899 a valuable paper was published by His in which he described for the first time clinically, the unusual complication known as blocked heart or atrioventricular allorhythmia. In 1901 August Hoffmann considered the neuroses of the heart and bloodvessels of sufficient importance to justify separate consideration. His treatise on the subject was shortly followed by those of Cassirer and Ludwig Krehl. We are indebted to these authors for the systematic presentation of the neuroses of the heart, including the Adams-Stokes complex; however, it is necessary to supplement their statements by reference to the very able reports that have appeared since, especially those of Luce (1902), Jaquet (1902), Lewy (1902), and Osler (1903). A fair idea of the general literature of the subject may be obtained from the painstaking review recently compiled by Edes (1901).

1 Read before the California Academy of Medicine, March 22, 1904.

voL. 128 , NO. 3-SEPTEMBER, 1904. 27 
It is proper to call attention at this point to the important services rendered in the development of functional heart diagnosis by von Basch, to whom we owe the sphygmomanometer. Mention should also be made of Schott, Gräupner, and of $A$. Smith, who have done much to perfect mechanical methods for the determination of the driving energy of the heart, and who have thereby aided materially in the investigation of the neuroses.

EтIOLOGy. A pulse rate under sixty is usually considered pathological, though Huchard states in his classification of the bradycardias that it is normally slow in some individuals. Napoleon is said to have had a pulse rate of 40 , but there is reason to believe, from the statements of Corvisart, that he was subject at times to peculiar seizures which have never been fully described. Bradycardia may be induced experimentally by irritation of the pneumogastric nerve, compression of the carotids, or by a rise of arterial pressure. It may at times be observed after childbirth and during the period of convalescence from acute articular rheumatism and a number of the infections. Schuster (1896), for example, describes a case in a child of four after an attack of acute articular rheumatism, with a pulse rate varying from 35 to 130 . The respiration was slow and irregular, and there were profuse swcats after each period of bradycardia. The case was probably one of acute myocarditis. Bradycardia may be caused by certain of the inorganic or organic poisons, and not infrequently is present in certain autointoxications, as, for example, in retention of bile salts without icterus (Brandenberg, 1903), and in the course of a number of morbid gastrointestinal hydrolyses. Slow pulse may occur in neurasthenia, hysteria, epilepsy, melancholia, amyotrophic lateral sclerosis, and tabes, but in none of these diverse conditions is the true clinical picture of the Adams-Stokes disease fully developed.

The Adams-Stokes complex most commonly occurs after middle life. It is rarely seen before the third decade. Of the twenty-five cases that $I$ have analyzed, 76 per cent. were over fifty years of age. Males are more frequently affected than females, the ratio being nearly three to one. Syphilis may be a contributing factor, but was present in only two cases. Curtin (1903) has noted bradycardia with convulsions after excessive use of tobacco. Alcohol appears to have a definite causal relation. In a few instances a life of exposure seemed to predispose, but this factor cannot be emphasized. In the cases of Balfour and von Schrötter traumatism seemingly played a part. The typical complex may be associated occasionally with sclerosis of the bulbar vessels and attendant anæmia of the vagus centre, or parenchymatous changes may be found in the peripheral filaments of this nerve. Abortive forms are met with in individuals of neuropathic tendency. In this group belong the peculiar attacks of temporary bradycardia with dizziness, partial loss of consciousness, or of transient weakness of the extrem- 
ities sometimes seen in neurasthenic or hysterical patients after periods of emotional excitement. These cases, as a rule, have a labile circulation and yield definite evidence of vasomotor instability.

Morbid Anatomy. The post-mortem findings are inconstant. Anatomical lesions of the heart and bloodvessels are relatively frequent. Artery degeneration may be widespread, but it is more common to find regional sclerosis. 'The fallacies that beset conclusions based upon macroscopic observation alone are clearly shown by the very thorough studies of Luce (1902). This author noted acute diffuse parenchymatous vagus neuritis with total disappearance of the axis-cylinder processes at many points, although at autopsy both vagi were regarded as normal, and nothing pathological was found in the medulla oblongata or the vagus centres. The arteries at the base of the brain sometimes present gross degenerative changes, but this is rather the exception than the rule. In the absence of accurate histological data, the greater part of the pathological reports at present available must be regarded with distrust. Undoubtedly in many instancés essential changes in the peripheral vagi have been entirely overlooked.

Among the conditions affecting the heart itself those due to interference with its blood supply arc most important. Sclerotic changes in the coronary vessels are frequently though by no means invariably present. Partial occlusion of one or both vessels may occur as the result of calcareous deposits at their points of origin. In one case, that of Sendler (1892), the vessel was partially occluded by the pressure of a primary fibroma of the heart.

In uncomplicated cases the heart is often not enlarged. Fragmentation of the muscle of the left ventricle has been reported, but in every instance must be regarded as an artefact. Fatty degeneration of the heart is not constantly present, as Friedreich thought, though it is common to find areas of fatty or fibrous myocarditis. The valves are often found intact in cases that had pronounced murmurs during life and gave every evidence clinically of extensive valvular disease. There may be imperfect alignment of the aortic segments, however, due to the presence of sclerotic nodules. In the remarkable case reported by Luce there was a primary roundcelled sarcoma of the heart of the size of a hazelnut situated in the right ventricle, which partially invaded both the aortic and pulmonic orifices and gave, rise to true bilateral obturating stenosis. As a rule there are no characteristic changes in the abdominal organs. The kidneys may be quite normal. Hoffmann (1901) quotes two cases of exceptional interest: that of Holberton, in which there were found narrowing of the occipital foramina, together with parenchymatous changes in the vagi and the superior cervical ganglion, and Lépine's case, due to compression of the pons and medulla. 
Sympтомs. Bradycardia, either permanent or recurrent, is always present, accompanied at irregular intervals by central nervous manifestations that are characteristic. The typical seizure may be preceded by a definite aura: sensations of weight and uneasiness in the epigastric region, or a sudden rush of blood to the head or extremities, are the more common. Stokes' patient was able to avert an impending attack by dropping on his hands and knees and holding his head down. Balfour mentions a parallel instance. His patient was able on one occasion to accomplish the same purpose while out walking by lying down in the road. In the fully developed attack there is sudden loss of consciousness lasting from a few seconds to hours, but usually of momentary duration. The patient falls; convulsive movements of the extremities ensue; the pupils are dilated; the respirations stertorous and at times of the Cheyne-Stokes type. The pulse rate is invariably diminished, and counts of 20 and under are not uncommon. In one case a rate of 5 was noted. There may even be gradual extinction of the radial pulse, with temporary cessation of heart action. In my case no pulse could be detected at the wrist during the attack. Various authorities claim to have heard indistinct tones or murmurs over the præcordia in the period of suspended activity. Hoffmann states that with the radiograph he was able to detect movements of the auricles while the ventricles were at rest. All attempts on my part to verify this observation were wholly fruitless owing to the impossibility of controlling the position of the patient during the convulsive phase.

The initial attack is usually of sudden onset and may affect an individual apparently in good health. In other instances there is an antecedent history of occasional dizzy spells extending over a considerable period. These prodromal attacks are, as a rule, of transitory nature and cause no particular inconvenience or apprehension. Once established, they tend to increase in frequency, though well-directed treatment will often give relief and even comparative immunity for some time. The attacks are subject to extraordinary variations both as regards frequency and severity. There may be several in the course of a day and then none for a week or more. Again, the seizures may be of hourly occurrence and lead rapidly to a fatal issue. I have frequently seen five or more in the course of an hour. His's patient had 143 in a single day. The exciting causes are indefinite, but it is certain that psychical factors play a much more important part than is generally stated. As a rule these patients are profoundly responsive to changes of environment, and under stress of emotional excitement may have frequently repeated seizures. In the milder attacks consciousness may be partially preserved and the patient able to maintain his balance by grasping near-by objects. In others loss of consciousness is absolute. Muscle movements set in, varying in intensity from 
fibrillary twitchings to the most powerful convulsions, and the patient finally recovers consciousness to find himself in the prone position with no definite idea of what has happened. As a rule there are no serious after-effects, and the general health in the free period is unimpaired.

Evidence of vasomotor unrest is seldom lacking. Extreme pallor of the face, alternate blanching or reddening, coldness of the extremities, and drenching sweats after the attacks are the most common signs. It is difficult to escape the conviction that vasomotor disturbances initiate the attack in a large number of cases. Both Ortner (1903) and Jaquet emphasize this point. This is less true of those cases that exhibit permanent vagus overaction than of the larger group of recurrent bradycardias which usually are of labile type and frequently have pulse rates above normal in the interval between attacks. It is in this latter class that the vasomotor influence is the more marked.

Certain anomalies of the circulation are of special interest:

1. Positive Centrifugal Pulsations of the Jugular Vein Exceeding in Frequency the Apex Beat. This remarkable phenomenon, the clinical description of which we owe to His, appears to be due to auriculoventricular asynchronism or allorhythmia. As Sahli has pointed out, if we accept the evidence yielded by the experiment of Stannius, namely, that the idiomuscular movements of the heart arise in the auricle and are propagated thence to the ventricle, and that it is possible to produce dissociated movements by interrupting the path of the impulse at the auriculoventricular border, it follows that a lesion at this point may cause independent auricular contractions, with no accompanying movements of the ventricle. This affords a logical explanation of the venous pulse observed by His. His' patient had a radial pulse rate of 18 to 32 exactly isochronous with the apex beat, while the jugular pulse ranged from 96 to 104 and was isochronous, with a low, humming murmur heard to the right and left of the sternum in the second and third intercostal spaces. One of Stokes' patients (Edmund Butler) affords a parallel example, though the phenomenon was less well marked. Blocked heart must be regarded as of very grave import. According to Belski (1902) it is peculiar to the terminal period of various cardiopathies and indicative of a dying myocardium. For reasons that are sufficiently obvious, the venous pulsations observed in blocked heart may be confined to the bulbus jugularis.

2. Heart Bigeminism or Pseudohemisystole. Hoffmann observed this form of arrhythmia in a young woman who was subject to syncopal attacks and had a pulse rate varying between 18 and 30 . According to Dehio it is possible to orient the causative lesion by the action of atropine. This drug will equalize the pulse rates at the heart and periphery if the vagus centre is involved, but not if the bigeminism is due to mural changes in the heart. 
Special Physical Signs. 1. Heart. Inspection may reveal little of objective value. The rib cage usually is stiff and its range of movement restricted. There is no bulging in the precordial region. In a majority of patients the apex impulse is very faint or invisible and frequently cannot be detected in any position. As a rule it is within the nipple line.

Clinical and pathological reports concerning the size of the heart are not in harmony. Very commonly there is no demonstrable enlargement. Moderate hypertrophy of the left ventricle occurs in the cases of diffuse arterioselerosis, and dilatation of the right ventricle usually takes place as a terminal event.

The heart sounds may be normal both at the apex and base. In some patients they are faint and distinguishable with difficulty; in others the tones are loud and ringing, with accentuation of the second aortic sound. Murmurs are relatively frequent. A soft blowing systolic murmur at the apex is the most common, but occasionally loud systolic murmurs are heard at every orifice, and it is astonishing over what a large area these sounds may be audible. Coincident pulmonary stiffiness and distention, to which von Basch and, later, Zuelzer (1901) called attention, may facilitate the diffusion of the sounds by offering a better vibratory medium. Alien tones of doubtful genesis occasionally invadc the heart cycle. They are usually low and indistinct and arise in the interval between the first and second sounds. It is necessary to exclude heart bigeminism. Very rarely low humming sounds may develop at the base; their significance has already been discussed in connection with heart block.

2. Arteries, Blood, and Blood Pressure. 'The peripheral arteries are often stiff and tortuous. This is especially true of the temporals, which may be very rigid and prominent. Arterial degeneration is not invariably present, however, as a large number of patients appear to have vessel tissue of good quality.

So far as I am aware the blood characters have never been worked out. Hoffmann's patient had 55 per cent. of hæmoglobin. Lewy states that he was unable to count the cells, as every attempt to withdraw a specimen precipitated an attack.

Huchard thinks that the blood pressure is high during the attack. No definite statements occur in the literature.

3. Urine. Hoffmann states that the secretion of urine is diminished before an attack, but admits that the evidence is not conclusive. In a large majority of patients it is of rather low specific gravity, free from albumin and sugar, and relatively negative.

Course and Prognosis. The outlook will depend largely upon the age and causative lesion. When the complex develops after middle life as a functional disorder in the absence of organic heart disease, the prognosis is favorable as regards life and the condition may be well borne for years. The outlook is, as a rule, 
favorable also in the abortive forms occurring in young individuals as the result of blood changes and psychical disturbances. Even in cases of more severe type the attacks may be withstood for ten years or more. Marked irregularity of the pulse, heart block, and other evidence of myocardial involvement are of the gravest import and may rapidly lead to a fatal issue. Death usually occurs in an attack.

Treatment. All attempts to cut short the characteristic attacks have so far been unsuccessful. Rest in bed should be enforced in all cases where the seizures are of daily occurrence. The foot of the bed should be elevated. Visitors, particularly those nearly related, should be excluded and every possible step taken to insure both mental and physical quiet. The diet should be simple and easily digestible. Tea, coffee, and tobacco must be absolutely prohibited.

Internal treatment is on the whole unsatisfactory. Potassium iodide in small doses-ten to twenty grains per day-is the most generally applicable remedy, and it may be given with benefit for long periods. Inhalation of oxygen is recommended by Hoffmann. Twenty-five to thirty litres may be taken daily for several months. The bromides are seldom of service. Digitalis is of doubtful value and must be used with extreme caution.

Residence in an equable climate is advantageous and should be recommended, together with instructions as to the avoidance of worry and physical exertion.

The pathological physiology of the Adams-Stokes complex is obscure. Of necessity it must remain a source of speculation until the causative factors are better understood. Taking into consideration the fact that a majority of all cases concern patients past middle life, and that it is customary to assume circumscribed or diffuse artery stiffness as an essential condition, it is natural to suppose that blood pressure studies would be instructive. On this important point, however, there are no authoritative statements in the literature.

The case I am about to present has been under observation nearly two years. During this period the object has been to accumulate trustworthy data on blood-pressure variations by making frequently repeated determinations. It will be necessary, therefore, to briefly describe the apparatus employed and the method of investigation, before proceeding with the clinical history of the patient.

All blood-pressure measurements were made with an improved form of the Riva-Rocei sphygmomanometer. This instrument is now so widely known that it will be unnecessary to describe it in detail. The apparatus is designed to register in millimetres of mercury the air pressure required to obliterate the pulse wave in the brachial artery. The arm band most commonly used in this country is about $5 \mathrm{~cm}$. in width, made of thin rubber protected by a 
jacket of canvas or duck, and is not provided with a rigid outer shell to prevent unequal distention. Müller (1902) in a simple theoretical discussion, made clear the inherent defect of this arm band and called attention to the fact that with it the normal values obtained are too high, ranging between 140 and $150 \mathrm{~mm}$. He adopted in preference one designed by von Recklinghausen, which is less open to objection. This form consists essentially of a thin rubber cylinder $15 \mathrm{~cm}$. in diameter, coated on the outer side with thin silk and applied around the upper arm by means of an ingenious double clamp. A strip of thin sheet brass of equal width is fitted smoothly over this and prevents unequal distention. With this band Müller obtained normal values varying from 105 to 115 $\mathrm{mm}$. A similar band made for me by Zimmerman, of Leipzig, was used in all blood-pressure determinations carried out in the course of this investigation.

Observations were made, as a rule, with the patient in a sitting position. The band was first applied to the bared arm at the level of the heart, and the patient instructed to assume an unconstrained attitude. After from fifteen minutes to half an hour of rest, pressure observations were made in triplicate. Readings were taken under three sets of experimental conditions: 1. At once after walking ten blocks at a slight up grade, omitting the fifteen-minute period of rest. 2. After rest for at least a quarter of an hour in a comfortable position. 3. Immediately after taking a prescribed amount of active exercise-walking and running in a room three minutes with no period of rest. No difficulty was experienced in obtaining concordant readings, the maximum variation never exceeding $2 \mathrm{~mm}$. Muscle movements of any sort introduce a gross error. For this reason it is impossible to determine blood pressure during typical convulsions.

Pulsertracings were taken with the ordinary Dudgeon sphygmograph. Unfortunately means were not at hand to determine the relation of the pulse curve to the respiratory cycle. A graphic presentation of the results, together with the conclusions deduced therefrom, will be introduced after reviewing the clinical history of the patient.

E. L., aged seventy-two years, a baker by occupation, applied for treatment at the Medical Dispensary of the University of California about June 5, 1902. He stated that the first symptoms of his trouble made their appearance in February of the same year. At that time he was working at his trade in a country town and was required to report for duty during the night. The actual onset was preceded for some days by indefinite symptoms. He was nervous, depressed, and had to urinate with unusual frequency during the day and four or five times at night. While on his way to work one evening he read a letter containing bad news; had what he describes as a rush of blood to the head, and fell unconscious to the ground. 
The attack quickly passed off, however, with no unpleasant aftereffects, and did not prevent him from engaging in his usual duties. Later in the evening, while stooping over the oven, an abortive attack was experienced, with a partial loss of consciousness and a feeling of suffocation and distress. Toward morning he again fell in a syncopal attack, but soon regained consciousness and was able to walk home. From this time on the seizures were of daily occurrence, forcing him within a short time to give up his work. A period of rest proved beneficial, but the trouble reappeared in May and induced him to consult a physician. The results of treatment were unsatisfactory. Indeed, under the influence of digitalis, which had been ordered for him, the attacks recurred with greater frequency, until finally, becoming alarmed about his condition, he moved to the city.

The following notes were taken at the medical clinic:

The patient was the youngest child in a family of nine. Both parents died at an advanced age. The father had been a hard drinker for years, but always enjoyed good health.

Patient was a delicate child. In his seventh year an ulcer developed on the posterior surface of the middle third of the right thigh, remained open several years, and from time to time discharged pieces of bone. Under treatment it gradually closed, but he was compelled to get about on crutches for several years. In his eighteenth year he.had pleurisy, does not remember which side was affected, but declares that the condition recurred once a year for seven years. It finally disappeared after a severe illness suggestive of typhoid fever, which occurred in his twenty-fifth year. After this for a considerable period he enjoyed good health, except when under the influence of whiskey, which he has used to excess since his thirtieth year. At the age of forty-eight a painless swelling developed on the dorsum of the right hand. It proved of transitory nature, but has frequently recurred. There is no definite history of rheumatism, except that at times he has had some stiffness of the right hip and knee. In his sixtieth and again in his sixty-second year he had severe attacks of pneumonia. During the past nine years his health has been good, and he has worked steadily at his trade. He positively denies any venereal infection.

Examination. Short, slightly stooped man of moderate musculature, fairly well nourished. The skin is soft and of good color; a few purpuric spots are present on the upper arms and shoulders; there is slight dermographia. The facial expression is dull. 'The lower eyelids are baggy. The pupils are rather large, equal, and react briskly to light and accommodation. There is a well-marked arcus. The ears are negative. The tongue is clean, the palate well arched, and the throat free of abnormalities. The teeth are bad. The mucous membranes where visible are of good color.

The thorax is symmetrically developed and roomy, though stiff 
and of limited mobility, the free costal borders slightly everted, the xiphoid angle wide. The apex impulse is neither visible nor palpable. On percussion the base of the heart is at the third cartilage, the apex half an inch inside the nipple line in the fifth interspace. The right border of dulness is at the left border of the sternum; the left border is $7 \frac{1}{2} \mathrm{~cm}$. from the median line.

At the apex there is a musical systolic murmur, faintly heard also in the midaxilla, but inaudible at the point of the scapula. It is clearly heard at the junction of the eighth rib with the anterior axillary line. In the second right interspace there is a musical systolic murmur which can be clearly heard in the right carotid

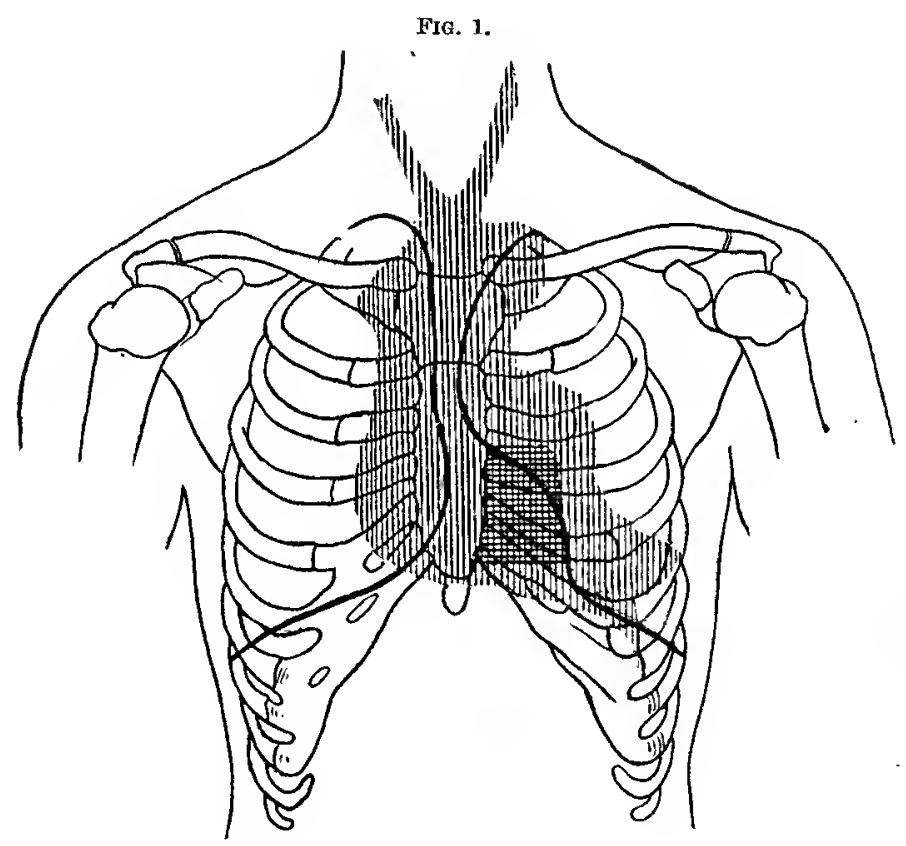

artery, less clearly in the left. The tone qualities of this murmur exactly coincide with that heard at the apex. The most painstaking examination failed to reveal convincing evidence of multiple valve lesions. Starting from a point of maximum intensity midway between the apex and aortic region, the murmur can be traced over a wide area corresponding roughly to an outline including the heart and arch of the aorta, with a margin about three inches wide (see Fig. 1). The basic tones are clear, and there is no duplication. The second aortic sound is slightly accentuated. The tricuspid region is negative. There are no pulsations in the veins of the neck.

The radial and femoral arteries are neither hard nor tortuous, while the temporals, on the contrary, are rigid and prominent. The 
pulse rate in the radial artery is 40 , corresponding exactly to the apex beat. The pulse is occasionally intermittent.

The blood contains 10,000 leukocytes, 5,790,000 erythrocytes, and 88 per cent. of hæmoglobin. A second leukocyte count several days later gave 6600 cells.

The breath sounds are clear and very harsh, inspiration is somewhat prolonged, and there is slight dyspnœa on exertion.

The abdomen is flat, with no inequalities, and the reflexes are intact. There are no sensitive points. The liver is not enlarged; its lower border is smooth and barely palpable. The spleen is negative. The kidneys cannot be felt. The urine is clear, of lightamber color, sharply acid, and a normal mucous cloud separates on standing. The specific gravity is 1020 . There is a faint trace of albumin, but no sugar. In the sediment there are large numbers of barrel-shaped crystals of uric acid. There is very little epithelium, not more than represents the normal desquamation from the bladder wall. A few unaltered red blood cells are present, but no pus. There are a few hyaline and finely granular casts.

The left thigh is smaller than the right and shows a linear, deeply depressed scar in the middle third posteriorly. In both legs below the knees there are a few small varicose veins, but no œdema.

There are no disorders of sensation: heat, cold, and pain reactions are intact. The knee jerks are lively, the left more pronounced than the right. 'The cremasteric reflex is present, but very sluggish.

$\mathrm{He}$ is positive that his trouble has been greatly aggravated by the action of digitalis, which he has been taking for some weeks. When he-first came under observation he had many attacks daily. It was not uncommon to count ten or more in an hour. At times the slightest disturbance-speaking harshly, or slamming a doorwould precipitate a seizure. Raising the extended arm over the head was for a considerable time a certain provocative measure. He is able to predict the moment of onset by a sensation of blood rushing to the head, and at once adopts an attitude of absolute immobility. In the attack the head is held well down between the shoulders; the chin thrust forward; the eyes wide open, with dilated pupils; the expression very anxious. A chair or other support is suddenly grasped; consciousness is suspended; the respiration becomes stertorous; the body is bent forward on the hips; the arms and legs partly flexed and very rigid. This tonic condition is succeeded by irregular clonic contractions, which affect both extremities simultaneously, but quickly pass off, the whole attack lasting from five to fifteen seconds. The skin is moist with perspiration after the seizure.

The behavior of the pulse is characteristic. By careful palpation it is often possible to detect an oncoming attack. The pulse waves become less frequent, dropping from 40 to 26 or less, with perhaps slight arrhythmia, then fade out entirely, and the heart ceases to 
beat. By consulting Fig. 2 it will be seen that absolute heart rest occurs some time before the convulsive phase, since the slightest movement of the wrist tendons suffices to disturb the tracing device. At $c$, Fig. 2, the beginning of the muscle tremor is plainly indicated.

FIG. 2.

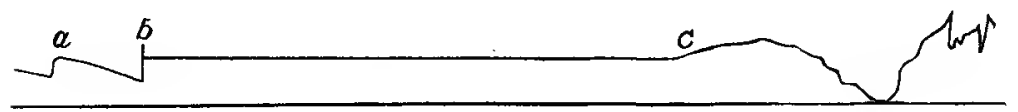

In order to obtain a tracing characteristic of the period of heart rest, it was necessary to apply the sphygmograph, await an attack, and then liberate the recording mechanism at the moment of heart rest. Unfortunately this gives no clue to the pulse characters before the onset. The sphygmograms taken in the free period vary very little in their general form. The tracing shown in Fig. 3 illustrates the

Fig. 3.

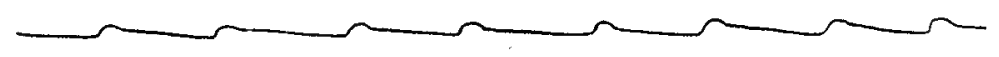

essential features, especially the gradual decline, with no dicrotism. The period of heart immobility does not terminate at the beginning of muscle movements; on the contrary, it persists throughout the attack. No sound could be heard over the præcordia at this time. Repeated attempts were made with the radiograph to investigate the heart movements during a seizure. Little of value was noted, however, owing to the suddenness of onset, brief duration, and the violent movements of the body.

A simple dietary, mostly liquid, was ordered, the tincture of digitalis withdrawn, and small doses of nitroglycerin substituted. After a week, no definite improvement being noted, the nitroglycerin was replaced by potassium iodide, five drops of the saturated solution three times daily. Within a short time marked improvement became apparent. The pulse, which previously had ranged between 30 and 40 in the free period, now rose to 72 . The syncopal attacks became less frequent, and toward the end of July entirely ceased. The patient was dismissed from the clinic at his own request.

On October 11, 1902, he again applied for treatment, having had several dizzy spells during the past week. . Reports that he stopped taking the iodide solution shortly after leaving the clinic. During September he had fair health, but latterly has been "seeing black." A physician who attended him recently ordered digitalis and nitroglycerin. Three days thereafter the typical seizures reappeared. He had two attacks while undergoing examination, which were rather less severe than those previously seen, At the wrist the 
pulse rate was 62 , quite regular, corresponding exactly to the apex beat. The heart condition was unchanged. The urine was intensely acid and contained large numbers of uric acid crystals. The amount in twenty-four hours was 1575 c.c., with a specific gravity of 1018. Between the 11th and the 23d of October he took twenty drops of saturated solution of potassium iodide every day. The pulse rate averaged 72 ; the subjective condition was good and he had no attacks.

On May 21, 1903, he reported that he had had no fainting spells since October. At times, especially in foggy weather, he has had some dizziness, but in other respects he has been quite well. There was no change in the heart condition. The pulse for some time had been very slow, rarely exceeding 40 ; on that date it was 36 .

On March 7, 1904, the subjective status was excellent. He had been taking the iodide solution continuously since October, 1902. Occasionally, especially in foggy" weather, he had spells of "seeing black." He stated that the condition sometimes persisted for a minute or more. There were no new objective signs. The heart was unchanged. The murmur had the same distribution and characteristics last reported. The pulse was 38 and regular. The skin was soft, clear, and of remarkably good color. The urine contained a trace of albumin, was intensely acid, contained large numbers of uric acid crystals, and its specific gravity was 1020. A few hyaline casts were found.

FIG. 4.

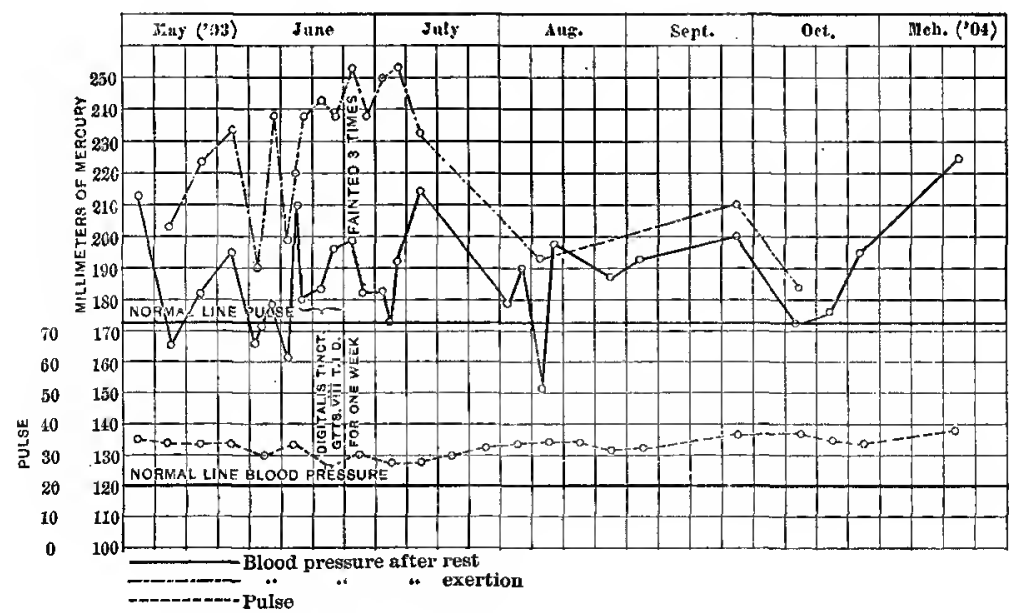

The blood-pressure observations were begun May 21, 1903, nearly a year after the patient was first seen, and some time after the last series of severe attacks. A graphic presentation of the results is given in Fig. 4. 
The following general conclusions are drawn from the experimental data obtained:

1. The blood pressure is constantly very high, ranging from 170 to $250 \mathrm{~mm}$.

2. The great arterial trunks of the extremities are fairly elastic.

3. Although very high blood pressure has existed for at least a year, the urine is normal in volume and specific gravity; there is little evidence of diffuse interstitial nephritis or of left ventricular hypertrophy. From this it follows that the high pressure is well borne by the heart and kidneys.

4. Active exercise, as a rule, has no accelerating action on the pulse. I have never counted an increase greater than two waves per minute. On the other hand it occasionally exaggerates the bradycardia.

5. Exercise invariably causes a sharp rise of pressure.

It seems difficult to harmonize such contradictory findings with the prevailing theory of the circulation. It will be sufficient to emphasize the most conspicuous anomaly, namely, the manifest disparity between the laggard work of the heart and the tremendous pressure at the periphery. This would appear to be too great to permit of explanation by a theory which assigns to the left ventricle almost the entire work of overcoming the inertia of the blood column. In the light of recent knowledge there is reason to believe that the arterial system and the vast capillary network of the periphery constitute a powerful secondary mechanism in constant rhythmic activity. It will be apparent that such a supposition denies that the heart wall generates the entire motive power, assuming on the contrary that other portions of the blood vascular system contribute a large quota of the driving energy. It is well to bear in mind in this connection that the whole arterial structure has perfect anatomical continuity.

Hasebroek (1903) has attempted to establish a new theory of the circulation, which gives this secondary apparatus a more definite value. Whether his dictum regarding the motor function of the peripheral vessels may be accepted is open to debate. There is confirmatory evidence in support of such a view, however, and it affords a logical explanation of a number of vascular phenomena that are otherwise almost wholly inexplicable. It would be entirely beyond the scope of this paper to consider in detail the arguments for and against such a view, but it is my belief that the so-called Adams-Stokes phenomena are highly suggestive of the existence of such an auxiliary mechanism dominated by the vasomotor system. The mode of action of psychic and other stimuli which are able to produce unstable equilibrium of this balanced heart and peripheral machine remains doubtful, but it is safe to assume that in the future this problem is destined to occupy a much more conspicuous place in the annals of research. 


\section{LITERATURE.}

Adams. Dublin Hospital Reports, 1827, vol. iv. p. 396.

Balfour, G. W. The Senile Heart, London, 1894, pp. 91-114.

Barozzi, J. Le pouls lent permanent, Presse méd, 1896, No. 83.

von Basch. Die Herzkrankheiten bei Arteriosclerose, Berlin, 1901, p. 27.

Belski, W. Ueber die an der A.-V.-Grenze blockirten Systolen, Zeitschr. f. klin. Med., 1902,

Bd, xliv. p. 179

Berguignan. Le traitement renal des cardiopathies artérielles, Paris, 1902, p. 34.

Brandenburg. Arch. f. Anatom. n. Physiol. (Physiol. Abteil), 1903, Suppl., pp. 149-191.

Cassirer. Die Neurosen, 1901.

Curtin, R. G. Bradycardia as a Symptom, American Medicine, 1903, No. 5, vol. vi. p. 188.

Dehio, K. Ueber die Bradycardia der Reconvalescenten, Deutsches Arcbiv f. klin. Med., 1893, Bd. lii. p. 74.

Dehio, $K$. Ueber den Einfluss des Atropin auf die arythmische Herzthätigkeit, Deutsches Arcb. f. klin. Med., 1893, Bd. lii. p. 97.

Edes, R. T. Slow Pulse with Special Reference to Adams-Stokes Disease, Philadelpbia Medical Times, August, 1901, p. 264.

Edgren. Die Arteriosklerose, Lei pzig, 1898, p. 216.

Friedreich. Krankheiten des Herzens, 1867, p. 179.

Gerhard t, D. Ueber Herzmuskelerkrankungen, Würzburger Abhandlungen, 1902, Bd. lii., Heft 2, S. 50 .

Gräupner. Die mecbanische Prüfung und Beurtheilung der Herzleistung, Berlin, 1902 (Ber-

liner Klinik., Heft 174).

Grob. Bradycardie, Deutsches Arch. f. klin. Med., 1888, Bd. xlii. p. 574.

Hasebroek, K. Versueh einer Theorie der gymnastischen Therapie der circulationsstörungen auf Grund einer lleuen Darstellung des Krelslaufes, Deutscbes Arch, f, klin. Med,, Bd. Ixxvij. p. 350.

His, W., Jr. Fall von Adams-Stokes Krankheit mit ungleicbzeitigen Schlagen der Vorhðfe und Herzkammern (Herzblock). Deutsches Areh. f. klin. Med., 1899, Bd. lziv. p. 316.

Hoffmann, A. Zur Kenntniss die Adams-Stokes'schen Krankheit., Zeitschr. f, klin. Med., 1900, Ba. xli. p. 358.

Hoffmann, A. Pathologie und Therapie der Herzneurosen und der Functionellen Kreislau fsstörungen, Wlesbaden, 1901, p. 271.

Holberton. Transactions of tbe Royal Medico-Chirurglcal Society, London, 1841. (Cited by Hoffmann.)

Hucbard. Traité clinique đes maladies du Coeur. Paris, 1899, 1. 395.

Jaequet. Ueber die Stokes-Adams'schen Krankheit., Deutscbes Archiv f. klin. Med,, Bd. ixxil. p. 77.

Jones, H. Slow Pulse with Seizures of Epileptoid Cbaracter, Lancet, December 2, 1876, p. 813. Kornmann. Einen-Fall von cardialer Bradycardia nach Ueberanstrengung, Inaug. Dissert., Zurich, 1901.

Krebl, L. Nothnagel's Spec. Path. u. Ther., 1901, Bd. xv. p. 352 . Die Erkrankungen des Herzmuskels u. đ. nervösen Herzkrankheiten.

Krehl, L. Pathologisebe physiologie, 1898, p. 32.

Lépine. Cited by Hoffmann.

Lewy, B. Ein Fall von Adams-Stokes'schen Krankbeit., Zeitscbr. f. klin. Med., 1902, Bd. xlvii. p. 321.

Luce. Adams-Stokes'schen Symptomencomplexes (zur Klinik und pathologischen Anatomie des), Deutsches Archiv f. klin. Med., 1902, Bd. Ixxiv. p. 369.

Moritz. Ein Fall einseitiger Bradycardia, Petersburg med. Woch., 1897, Bd. xxii. p. 32. In Schmidt's Jahrbucher, 1898, p. 198.

Müller. Deutsches Arch. f. klin. Med., 1902, Bd. 1xxiv. p. 321.

Ormerod, C. Note on a Case of Bradycardia, Lancet, 1899, p. 513.

Ortner. Zur Klinik der Angiosklerose der Darmarterien (Dyspragia intermittens angioselerotica intestinalis) nebst einem Beiträge zur Klinik des intermittirenden Hinkens und des Stokes-Adams'schen Symptomenkomplexes, Sammlung klin. Vorträge. Von Volkmann, Neue Folge, No. 347, Ieipzig, 1903, p. 899 ff.

Osler, W. Slow Pulse and Syncopal Attacks, Lancet, February 27, 1897.

Osler, W. On the So-called Stokes-Adams Disease (Slow Pulse with Syncopal Attacks, etc.), Lancet, August 22, 1903, p. 516 .

Petrina. Pulsverlangsamung und Arythmie nacb klein Dosen von Pilocarpinum muriaticum, Deutsches Archiv f. klin. Med., 1878, Bd. xx. p. 416. 
von Recklinghausen. Ueber Blutdruckmessung heim Menschen, Arch. f. experiment. Pathologie, Bd. xlvi. p. 105. (Cited by Müller.)

Rehfisch. Prognose der Herzarhy thmie, Deutsche med. Woch., 1903, pp. 347-373.

Riegel, F. Ueber Verlangsamung der Schlagfolge des Herzens, Zeitschr. f. klin. Med., 1890, Bd. xvii. p. 221.

Riegel, F. Ueber Herzbigeminie und Hemisystole, Deutsche med. Woch., 1903, p. 795.

Rosenbach. Berl. klin. Woch., 1903, p. 1065.

Sahli. Klinischen Untersuchungsmethođen, 1901, p. 308.

Schrötter, L. von. Nothnagel's spec. Path. u. Therap., Erkrankungen der Gefässe, 1901, Bd. xv., Theil 3, p. 113.

Schuster. Zur kardialen Bradycardie, Deutsche med. Woch., 1896, p. 30.

Sendler. Beitrag zur Frage ueher Bradycardie, Centralhl. f. klin. Med., 1892, No. 31.

Silbergleit. Beitrag zur Lehre von der Cardialen Bradycardie, Zeitschr. f. klin. Med., Bd. xlviii. p. 145.

Smith, A. Ueher den heutigen Stand der funktionellen Herzdiagnostik und Herztherapie, Berlin, 1902 (Berliner Klinik, Heft 166).

Stokes, W. Diseases of the Heart and Aorta. German translation hy J. Lindwurm, Würzburg, 1855, p. 285.

Wenkebach, K. F. Zur Analyse des unregelmässigen Pulses, Zeitschr. f. klin. Med., 1900, Bd. Xxxix. p. 302.

Zuelzer, G. Zur Symptomatologie und Therapie der chroniscben Lungenblähung (Vagusneurose), Berl, klin. Woch., 1901, p. 1277.

\title{
BORATED FOOD AS A CAUSE OF LESIONS OF THE KIDNEYS.
}

\author{
By Charles Harrington, M.D., \\ ARSISTANT PROFESSOR OF HYGIENE, HARVARD MEDICAI BCHOOL,
}

OF the various chemical preservatives of food, the two most commonly employed are borax and boric acid, and these are used very largely together. They are used so extensively that it is safe to say that not only in the cities and large towns where the commercial importance of chemical preservatives is so great, but in the country at large, persons of all ages are likely to receive frequent, if not daily, doses of one or of the other or of both. They are added to milk, butter, oleomargarine, and some forms of cheese; they are almost always present in opened clams and oysters; they are applied externally to fresh meats to prevent sliminess and to fresh and salted fish; they are important constituents of the brine in which meats are pickled and corned; their solutions are injected into hams and other pork products, and they are to be found in almost every known make of sausages in the market, even those which are put up in hermetically sealed cans. It is commonly and correctly supposed that canned foods, having been subjected to the process of sterilization, need no chemical preservative; but these agents are used in canned sausages, not to prevent decomposition, but because they increase the water-retaining capacity and prevent the sausage contents from contracting and thus causing the casing to appear loose and wrinkled. 